International Journal of Life Sciences
Available online at http://sciencescholar.us/journal/index.php/ijls
Vol. 2 No. 3, December 2018, pages: 121 135
e-ISSN: 2550-6986, p-ISSN: 2550-6994
https://doi.org/10.29332/ijls.v2n3.221

\title{
Analysis and Design of Wastewater Treatment
}

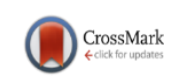 \\ Jordan Andres Ponce Pinoargote a, Jennifer Tatiana Roman Alcivar ${ }^{b}$, Carlos G. Villacreses Viteri c \\ Article history: Received 20 July 2018, Accepted: 30 August 2018, Published: 15 November 2018
}

\section{Correspondence Author a}

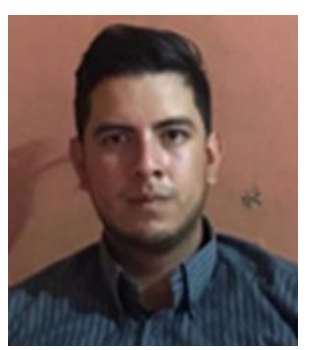

\section{Keywords}

Agricultural;

Irrigation;

Sewage;

Wastewater;

Water treatment;

\begin{abstract}
The work proposes the reuse of wastewater from the Faculty of Agronomic Engineering of the Technical University of Manabí, located in the Lodana parish in the city of Portoviejo, to irrigate the diversity of plantations that exist in the institution as a banana, cocoa, and lemon. In the work, the results of the physical-chemical and bacteriological analysis carried out on the residual water generated in the institution are offered, being able to verify that it does not meet the parameters required to be used in the irrigation of crops. The technical scheme of the proposed treatment system is shown, specifying the structure of the zeolite filter. The calculations made for the technical and structural design of each of the devices that make up the proposed treatment system are provided. The analysis of the performance of the system that is illustrated with a series of data reflected in tables is exposed and where an efficiency between $84 \%$ and $88 \%$ can be verified. A review of compliance with environmental regulations is carried out and an economic analysis is provided on the cost of the investment for the introduction of the system in the Faculty of Agricultural Engineering of the Technical University of Manabí.
\end{abstract}

e-ISSN: 2550-6986, p-ISSN: 2550-6994C Copyright 2018. The Author. SS Journals Published by Universidad Técnica de Manabí. This is an open-access article under the CC BY-SA 4.0 license (https://creativecommons.org/licenses/by-sa/4.0/) All rights reserved.

\section{Contents}

Abstract 121

1. Introduction 122

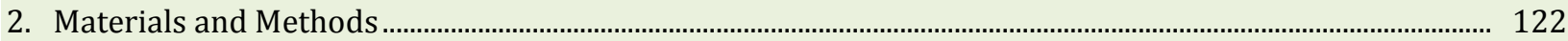

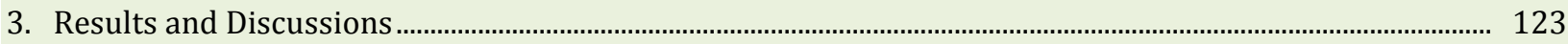

3.1 Wastewater: Historical evolution of its treatment .................................................................................... 123

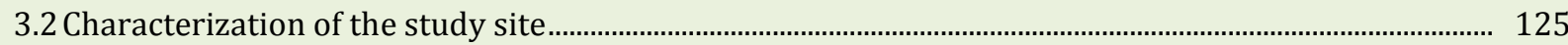

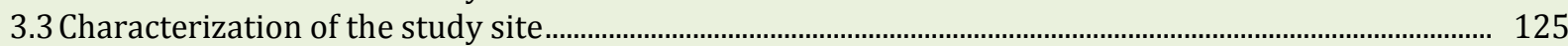

a Universidad Tecnica de Manabi, Portoviejo, Ecuador

b Universidad Tecnica de Manabi, Portoviejo, Ecuador

c Universidad Tecnica de Manabi, Portoviejo, Ecuador 
3.4 Technical diagram of the alternative wastewater....................................................................................... 126

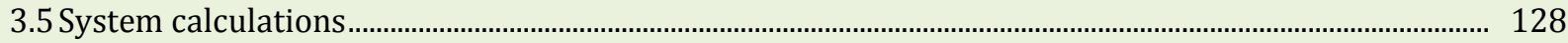

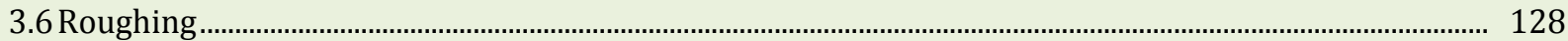

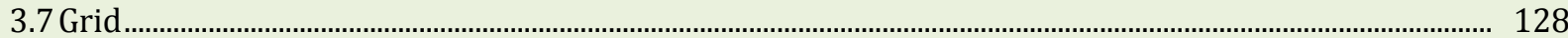

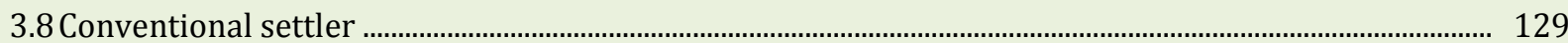

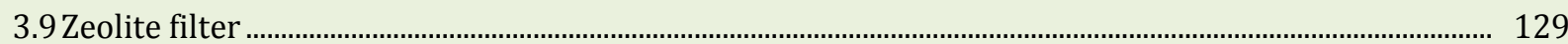

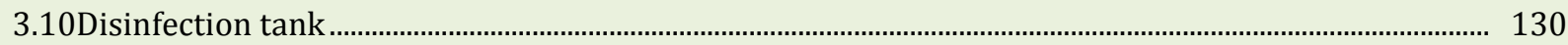

3.11Total performance of the wastewater treatment system ……..................................................................... 130

3.12 Review of compliance with environmental regulations................................................................................. 132

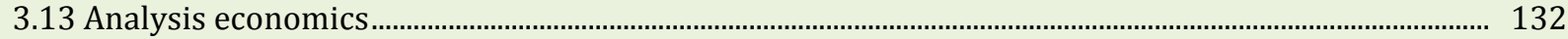

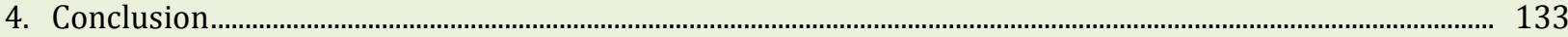

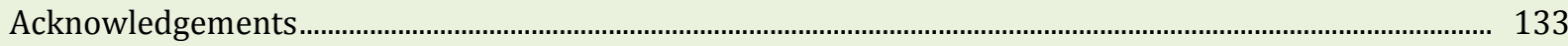

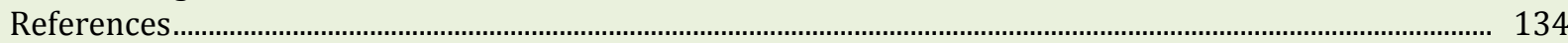

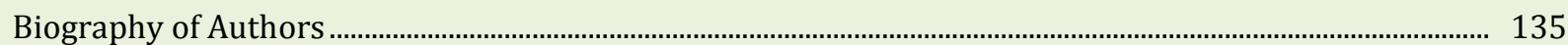

\section{Introduction}

Water quality for irrigation is important for safety reasons, due to its potential effect on human health and ecosystems in general (García, 2015). The poor quality of water used in irrigation is one of the reasons that justify the presence of pathogens in vegetables such as tomatoes and lettuce (Castellón et al., 2015). The concept of water quality for irrigation refers to water characteristics that may affect soil and crop resources in their long-term use (Lenntech, 2018).

The reuse of wastewater is an important option in integrated water resources management (IWRM), which addresses all aspects of this cycle and optimizes the use of water in all its forms. The 2002 World Summit on Sustainable Development (UN, 2002) called on countries to develop IWRM and water efficiency plans. This approach includes, among other aspects: the evaluation of water needs in collaboration with end users; the examination of all available water sources and; the adjustment of water supplies to the needs based on the quantity, quality and reliability required for the various purposes and the costs of supply in relation to the benefits in each case.

The regeneration of wastewater and its reuse in agriculture is having wide acceptance in many parts of the world (Morillo, 2017). That is why the work proposes a technological design for the treatment of wastewater so that it can be recycled and used for irrigation to benefit the Faculty of Agricultural Engineering, with the help of various regulations in force in Ecuador.

A treatment device for the reuse of wastewater is proposed in the Faculty of Agronomic Engineering of the Technical University of Manabí, in order to generate irrigation waters for the crop plantations that the institution has. The objective of the work is to analyze and design a wastewater treatment system in the Faculty of Agronomic Engineering; from the problem that exists when the soil of the blind well becomes saturated, causing wastewater to become impoverished, and this, in turn, causes difficulties such as mosquito breeding sites, unhealthiness, risk of contagion of diseases, bad odors, contamination, etc. ; This design will have the purpose of generating water for irrigation, given that the School has short-cycle crops that require programmed irrigation.

\section{Materials and Methods}

In order to achieve the reuse of wastewater generated in the Faculty of Agronomic Engineering as a source for irrigation, the resources and statistics provided by the staff working in the institution were used, as well as the various visits that were made to make the water samples, the soil samples and the topography of where the project is going to be carried out. After processing the information, examining and characterizing the effluent, we proceeded to define the type of treatment technology that is needed according to the minimum necessary parameters and then design it. 
For the investigation, the analysis of the results of research projects carried out at the Technical University of Manabí Loor \& Murillo (2017) was considered, where the use of zeolite for the reduction of wastewater pollution in the city of Portoviejo is proposed.

The soil studies that are attached for the evaluation were carried out by the researchers at the Technical University of Manabí, while the water analyzes were carried out in the wastewater treatment plant (WWTP) of the city of Portoviejo; in which the researchers were part of the samples taken at the Faculty of Agricultural Engineering. According to the parameters, an input structure was designed, that is, a screening, an aerator mechanism, then a primary settler, the zeolite filter, and a disinfection system.

The type of process chosen for the treatment device of the Faculty of Agronomic Engineering is a conventional type that consists of a screening, this pretreatment is essential, because if the materials that reach the filtrate are not eliminated effectively, they can produce serious faults in the filter system; a primary settler, which carries out a natural physical decantation for the removal of suspended solids and a natural flotation of the less dense particles that could not be eliminated in the pretreatment; a zeolite filter that turns out to be efficient in reducing the level of water pollution (Alcivar et al., 2017), especially in the reduction of ammonium and a disinfection system, to finally proceed with a facultative lagoon of treated wastewater and that constitutes the water source for irrigation.

The application of a conventional treatment system to wastewater from the Faculty of Agricultural Engineering will allow having a volume of water for the irrigation of plantations that this institution has. The research has been based on the experimental descriptive and field type, studies of photographic documentation and the available bibliography; in addition to the collection of elements and technical criteria obtained from authorities of the Technical University of Manabí, which provided the fundamental guidelines to establish the study. Dependent and independent variables were observed and the techniques required to develop the research were generated.

One point was selected to extract samples of residual water and another to perform the soil study and the initial values of the parameters established for the study were quantified, this allowed to analyze all the results and choose an adequate design for the treatment of wastewater from the Faculty of Agricultural Engineering of Lodana. The first data collected were obtained by the quantification of the use of the bathrooms by the students, for this the discharges of the toilets were taken into consideration, the expense generated by the sinks and urinals, once the analysis of this information was made it was possible to estimate an approximate flow that was considered for the design of the water conduction system and the treatment technology. The estimated wastewater flow is $4.62 \mathrm{l} / \mathrm{s}$, which is obtained by measuring the effluents that exist in the facility.

For the design of the sewerage system, the Ecuadorian Code for the Design of the Construction of Sanitary Works was used under the Standard CO 10.7601 and 602 (INEN, 2017), as well as the design standard for potable water supply systems, provision of excreta and liquid waste in rural areas (Morales, 2017).

The system uses pipes with an external commercial diameter of $175 \mathrm{~mm}$ that will not create any problems in the transportation of the fluids to the purification device, the norm mentioned above dictates that the minimum slope for sewage pipes is $3 / 1000$ being this the adopted for the project.

\section{Results and Discussions}

\subsection{Wastewater: Historical evolution of its treatment}

Wastewater is any type of water hose quality was negatively affected by influence anthropogenic. These include those for domestic use, urban waste and industrial or mining waste eliminated or water that was mixed with the previous (rainwater or natural) (Garcia, 2015).

When we talk about wastewater, we tend to relate them to a multitude of problems; since humanity has stored and distributed water practically since its origins. From the first storage, cleaning and distribution techniques to the current infrastructures and technologies for the treatment, recycling, and purification of water, a long history has passed (Castellón et al., 2015).

Pinoargote, J. A. P., Alcivar, J. T. R., \& Viteri, C. G. V. (2018). Analysis and design of wastewater treatment. International Journal of Life Sciences, 2(3), 121-135. https://doi.org/10.29332/ijls.v2n3.221 
The Egyptians were the first to use methods for water treatment. These records date from more than 1,500 years ago until $400 \mathrm{BC}$ They indicate that the most common form of water purification was obtained by boiling it over the fire, heating it to the Sun or submerging a piece of hot iron inside it (Castellón et al., 2015).

The first sanitation facility was the blind well, which appeared in Babylon around $4000 \mathrm{BC}$, which consists of a simple excavation in the ground to concentrate the excrement that soon spread to other cities of the empire and rural areas. The Babylonians had already developed an incipient hydraulics for the transport of water and soon applied their knowledge to the conduction of the feces to the black wells by means of the washout and the first clay pipes. That is how the black waters were born, inseparable companions of civilization up to the present day and a technology associated to live with them: sanitation (Morillo, 2017).

By then the water supply had reached the cities, but it was not until $3000 \mathrm{BC}$ that in the city of MohenjoDaro, in the Indus valley (in present-day Pakistan), the first buildings with latrines connected to sewers in streets. The citizens washed their latrines with water and the sewers collected the wastewater and took it to the blind well or the Indus River. The problem had grown in complexity and magnitude and began to systematically contaminate the water courses (Morillo, 2017). In ancient Greece, in the absence of large rivers, the first application of sewage for agricultural fertilization arose. In some cities, the sewers carried the black waters from the outskirts of the city to a landfill, from which they were transported by ducts to the fields (Morillo, 2017).

Of the many primitive sewers that have been described, the grand underground drains of ancient Rome are the best known. Based on the writings of the time, it is known that the direct connection of the houses to these drains was not widespread, due to the absence of a recognition of public health requirements; In addition, compulsory sanitation would have been considered as a violation of the private law (Ramolho, 1996). The development of wastewater treatment systems became more evident in the 20th century. But the biological elimination of phosphate is the only process that has been discovered by accident, and the first evidence of biological phosphate removal occurred in India in a wastewater treatment process.

This showed that the consumption of phosphate was linked to a biological process (inhibition by toxic substances, oxygen requirement). Later, this process was called improved biological phosphate removal and was observed in other wastewater treatment plants (Lenntech, 2018). In the treatment of wastewater what you want to achieve is to remove the materials that are possible to sediment, using physical or physicalchemical treatments. In certain cases, simply leaving the wastewater for a while in large tanks or in the case of improved primary treatments, adding to the water contained in these large tanks, chemical substances that make sedimentation more expeditious and stronger. These treatments include neutralizing the $\mathrm{pH}$ and eliminating volatile contaminants such as ammonia (desorption). The operations included are deoiling and degreasing, primary sedimentation, filtration, neutralization and desorption (Condorchem, 2010).

Physical sedimentation is the process by which solids suspended in wastewater are allowed to settle by gravity. Bacteria growing in this medium, together with other solids, are removed in a secondary sedimentation tank and returned to the ventilation tank. In this type of treatment, you can remove between $60 \%$ to $65 \%$ of the settleable solids and $30 \%$ to $35 \%$ of the suspended solids in the wastewater. It can also be found in special physical and chemical processes that cleanse contaminants such as phosphorus, nitrogen, minerals, heavy metals, viruses, organic compounds, etc. It is a type of treatment more expensive than the previous ones and it is used in more special cases like for example to purify waste of industries. Sometimes the tertiary treatment is used to improve the effluents of the secondary biological treatment. Rapid filtration in the sand has been used to better eliminate suspended solids and nutrients and reduce the biochemical oxygen demand (Condorchem, 2010).

A better possibility for tertiary treatment is to add one or more ponds in series to a conventional treatment plant. Adding these depuration ponds is an appropriate way to improve an established wastewater treatment plant so that effluents can be used to irrigate crops or green areas and in aquaculture (López-Vázquez et al., 2017). In recent decades the world has been showing concern and is trying to solve the problems related to the disposal of liquid effluents from domestic, commercial and industrial use of water supply; and the lack of treatment plants for wastewater in cities and in industries, hotels, mining, agricultural and livestock, causing large volumes of polluted water that do much damage to the environment. Most of these waters are discharged into rivers, lakes, seas, open-air or subsoil soils, through so-called septic tanks, sanitary landfills and effluent discharges. 


\subsection{Characterization of the study site}

The Faculty of Agronomic Engineering of the Technical University of Manabí was created on July 30, 1968. It is located on the grounds of the hacienda "La Teodomira", $18 \mathrm{~km}$ from the capital city of the province of Manabí (Loor-Bravo \& Meza-Vélez, 2017).

Since the creation of the faculty and over the years has been modified, taking into account the technological advances of the time, according to local, provincial and national reality, in order to meet the needs and recommendations of the agricultural environment. In it there is a generation of wastewater from 4 bathrooms, two in the lower part of the building for both men and women and in the same way in the upper part; and 4 laboratories, three in the upper floor and one in the lower part; all these wastewaters are joined in well 1. On the other hand, the wastewater generated from well 2 comes from the bathrooms that are on the side of the faculty, but in turn, they are added to these wastewaters, which are infiltrated as a consequence of the irrigation activity, generating an increase in flow. In well 3, the wastewater generated by the bar is collected.

The faculty is composed of 15 teachers who are responsible for teaching subjects included in the career curriculum, with an enrollment of 550 legally enrolled students and 10 administrative and service workers. The facility consists of two buildings for academic purposes and another that corresponds to the administrative area, there are also areas suitable for short-cycle crops, in which students perform agricultural practices according to the subjects and graduates conduct research for their degree work ; the maintenance of the agricultural area demands the water resource that is of vital importance, which has led to looking for alternatives to supply water for irrigation.

The study of soil allowed to define that its type is organic clayey (Fair, Geyes, \& Okum) and its infiltration capacity is very low, that is, it is a very plastic soil; causing that during the hours in which the system is not used, they are not sufficient for the water to infiltrate, reason why this leads to generate inconveniences. In the same way, the discharge parameters were examined and compared with water quality criteria for agricultural use. Once the needs were analyzed, we proceeded with the design of the pollution reduction processes that are needed to use the water for irrigation.

\subsection{Characterization of the study site}

As part of the diagnosis in the field study, the physical, chemical and bacteriological parameters of the wastewater were evaluated. For this purpose, samples of the effluents were taken and laboratory tests were carried out. Table 1 shows the average results of the physical, chemical and bacteriological analysis of the samples taken from the wastewater. On the left side, the laboratory results obtained during the evaluation of the residual water are indicated; On the right side, according to the THUSMA standard, the quality that irrigation water must have an ISO 16075 for the agricultural use of treated wastewater (iagua, 2015), (Presidency, 2010).

Table 1

Results of physical-chemical and bacteriological analysis of wastewater

\begin{tabular}{|c|c|c|c|}
\hline Parameters & Results & $\begin{array}{l}\text { Limit } \\
\text { permissible }\end{array}$ & Compliance \\
\hline \multicolumn{4}{|l|}{ Physical } \\
\hline Conductivity $(\mu \mathrm{s} / \mathrm{cm})$ & $\begin{array}{l}1433 \mu \mathrm{s} / \\
\mathrm{cm}\end{array}$ & $3000 \mu \mathrm{s} / \mathrm{cm}$ & Complies \\
\hline Dissolved Oxygen, $\mathrm{LDO}(\mathrm{mg} / \mathrm{L})$ & $3.71 \mathrm{mg} / \mathrm{L}$ & $6,00 \mathrm{mg} / \mathrm{L}$ & Complies \\
\hline Dissolved Total Solids, STD $(\mathrm{mg} / \mathrm{L})$ & $714 \mathrm{mg} / \mathrm{L}$ & $3000 \mathrm{mg} / \mathrm{L}$ & Measures \\
\hline Total Suspended Solids, STS $(\mathrm{mg} / \mathrm{L})$ & $233 \mathrm{mg} / \mathrm{L}$ & $220 \mathrm{mg} / \mathrm{L}$ & Does not meet \\
\hline $\mathrm{PH}$ & 8.49 & $5.6-8.4$ & Complies \\
\hline Temperature, $T^{\underline{a}}\left({ }^{\circ} \mathrm{C}\right)$ & $17,40^{\circ} \mathrm{C}$ & $22,00^{\circ} \mathrm{C}$ & Meets \\
\hline
\end{tabular}

Pinoargote, J. A. P., Alcivar, J. T. R., \& Viteri, C. G. V. (2018). Analysis and design of wastewater treatment. International Journal of Life Sciences, 2(3), 121-135. https://doi.org/10.29332/ijls.v2n3.221 


$\begin{array}{llll}\begin{array}{l}\text { Chemicals } \\ \text { Total Hardness }\end{array} & 460 \mathrm{mg} / \mathrm{L} & 500 \mathrm{mg} / \mathrm{L} & \text { Complies } \\ \text { Phosphates, } \mathrm{PO}_{4} & 12 \mathrm{mg} / \mathrm{L} & 13 \mathrm{mg} / \mathrm{L} & \text { Complies } \\ \text { Nitrites, } \mathrm{NO}_{2} & 3 \mathrm{mg} / \mathrm{L} & 60 \mathrm{mg} / \mathrm{L} & \text { Meets } \\ \begin{array}{l}\text { Nitrates, } \mathrm{NO}_{3} \\ \text { Sulfates, } \mathrm{SO}_{4}\end{array} & 2 \mathrm{mg} / \mathrm{L} & 10 \mathrm{mg} / \mathrm{L} & \text { Meets } \\ \begin{array}{l}\text { Organic-biological } \\ \text { Oxygen Biochemical Demand (BOD5) }\end{array} & 61 \mathrm{mg} / \mathrm{L} & 250 \mathrm{mg} / \mathrm{L} & \text { Meets } \\ \begin{array}{l}\text { Chemical Oxygen Demand (COD) } \\ \text { Microbiological }\end{array} & 526 \mathrm{mg} / \mathrm{L} & 100 \mathrm{mg} / \mathrm{L} & \text { Does not meet } \\ & 998 \mathrm{mg} / \mathrm{L} & 250 \mathrm{mg} / \mathrm{L} & \text { Does not } \\ \text { MEETFecal Coliforms (CF) } & >240000 & 6000 \mathrm{NMP} / & \\ & \mathrm{NMP} / & 100 \mathrm{ml} & \text { Do not complete } \\ & 100 \mathrm{ml} & & \\ \text { Total Coliforms (López-Vázquez et al.) } & >240000 & 1000 \mathrm{NMP} / & \text { Does not meet }\end{array}$

The problematic is born of the emanation of wastewater on the surface of the soil. When the relevant tests were carried out, it was discovered that the soil was organic clayey (Fair et al.) And its infiltration capacity is very low

\subsection{Technical diagram of the alternative wastewater}

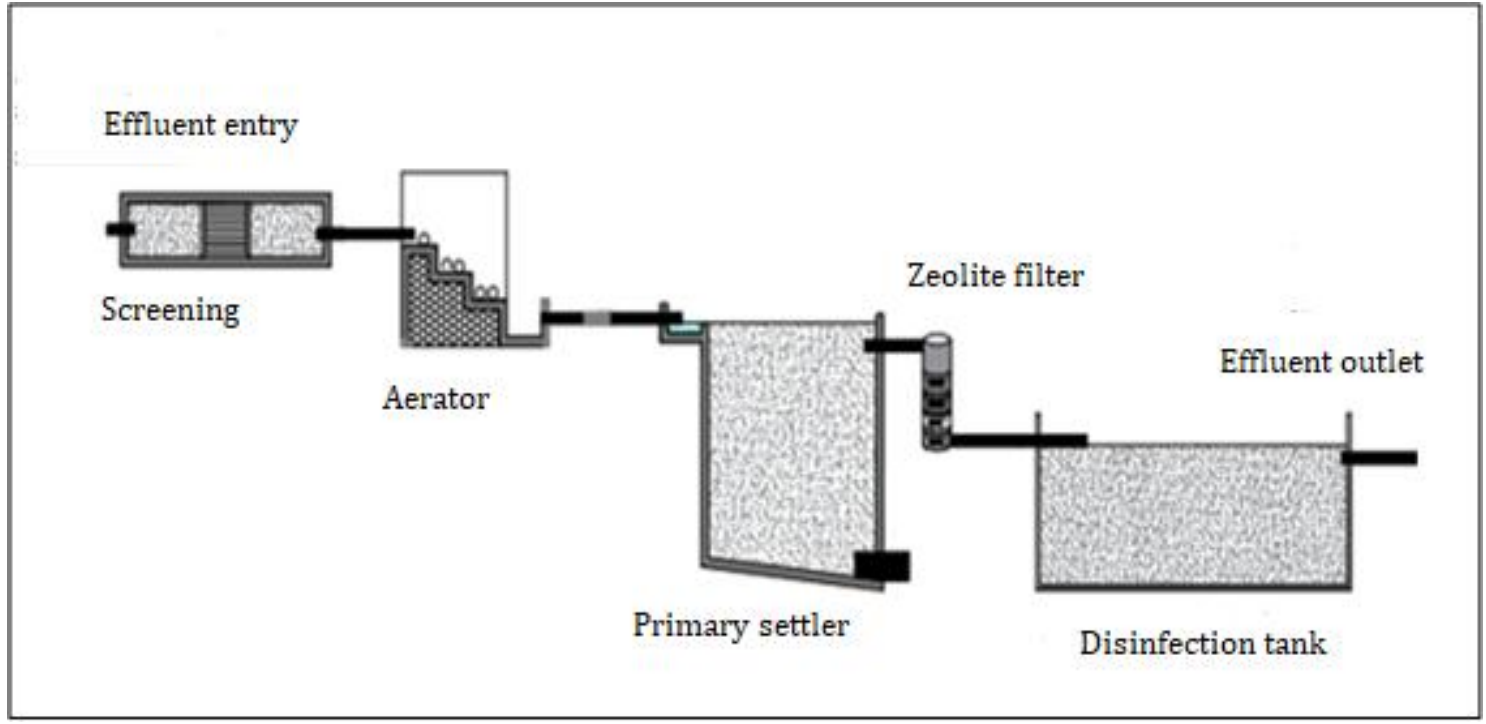

Figure 1. Alternative wastewater treatment technology

Screening is the first process of the treatment to which the residual water is subjected and this includes the roughing that has as objective to separate the solids of greater size and is carried out to protect the system from possible damages or obstructions due to large objects. Later the water enters the sand trap; which is responsible for once the solids of superior size have been eliminated, eliminating the small solids that escape the roughing, the sand trap also has the function of protecting the mobile mechanical elements of the abrasion, for the project a rectangular settler was used. The fat separators are the best compliment for the purification system. Eliminate fats and detergents from wastewater that comes from sinks, dishwashers, washing machines, etc. In this way the performance of the purification system is improved, preventing the clogging of the drainage system. These are designed according to the type of treatment and the flow that is generated. It is recommended to use one for the treatment referred to above. 
The second step in the process is the aerator that has the function of mixing and circulating or dissolving air inside the residual water to be treated. This process can reduce the number of chemicals needed to treat a body of water by supplying oxygen that bacteria need to do their job.

In the third step, the residual water is submitted to the sedimentation, which consists of a physical separation process by gravity that causes the densest particles in the water to have a downward trajectory, depositing themselves at the bottom of the settler. It is a function of the density of the liquid, the size, the specific weight and the morphology of the particles. This operation will be more effective the greater the size and density of the particles to be separated from the water, that is, the higher the sedimentation rate, being the main design parameter for this equipment. This sedimentation operation is also called decantation. The fundamental objective of primary decantation is twofold: on the one hand, it allows the removal of solids in suspension (approximately 60\%) present in wastewater and organic matter (approximately 30\%) and, on the other hand, they protect the subsequent processes of biological oxidation of the intrusion of inert muds of high density.

The fourth step is the secondary treatment using a zeolite filter, as described by Loor \& Murillo (2017) in the research project entitled "Evaluation of the removal of ammonium in wastewater, using particulate zeolite of different diameters". Zeolite (clinoptilolite) is a mineral of volcanic origin, formed naturally from ash and seawater, which is also present in Andean folds. Formerly it was widely used in Asia (China and India) as a natural supplement to promote organic health and well-being. It is a powerful heavy metal cleaning agent, supporting the immune system $100 \%$ bioavailable, ecological and natural (Fair et al., 1973).

The filter designed by Loor \& Murillo (2017) is used for flow rates of $4 \mathrm{l} / \mathrm{s}$ and is applicable to the estimated flow rates in the design. Figure 2 shows the technical scheme of the zeolite filter used in the system.

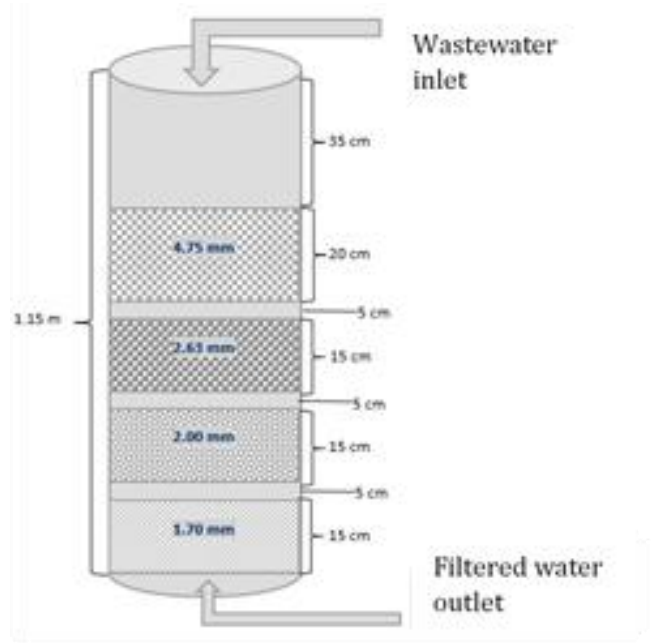

Figure 2. Zeolite filter used in the system

Because zeolite is a natural, non-polluting mineral, the impact to the environment is reduced to a minimum, the strongest impact to the ecosystem of the area in question is due to the movement of lands executed for the construction of the system

\subsection{System calculations}

The results of the residual water characterization of the Faculty of Agronomic Engineering of the Technical University of Manabí show that the parameters do not comply with the environmental regulations iagua (2015) in the following aspects: fecal coliforms, BOD5, COD, oils and fats.

The purpose of the wastewater treatment system design in the Faculty of Agronomic Engineering of the Technical University of Manabí is to ensure that the parameters that are outside the environmental

Pinoargote, J. A. P., Alcivar, J. T. R., \& Viteri, C. G. V. (2018). Analysis and design of wastewater treatment. International Journal of Life Sciences, 2(3), 121-135. https://doi.org/10.29332/ijls.v2n3.221 
regulations reduce their value until they are within the permissible limits established by the standard iagua (2015), thus achieving a reduction in the pollutant load caused by these parameters.

This is how, based on the above, the corresponding calculations were made for the design of the treatment

\subsection{Roughingroughing}

Chamber The chamber was designed from the application of equation 1 (Quiroz-Fernández, IzquierdoKulich, \& Menéndez-Gutiérrez, 2016), obtaining, as a result, a grid area of $0.125 \mathrm{~m}^{\wedge} 2$

$$
A_{G R I D}=\frac{Q_{\max }}{v}=0,125 \mathrm{~m}^{2}
$$

Offering as result chamber with 5 thin bars of rectangular section. Figure 3 shows the technical design of the grid chamber

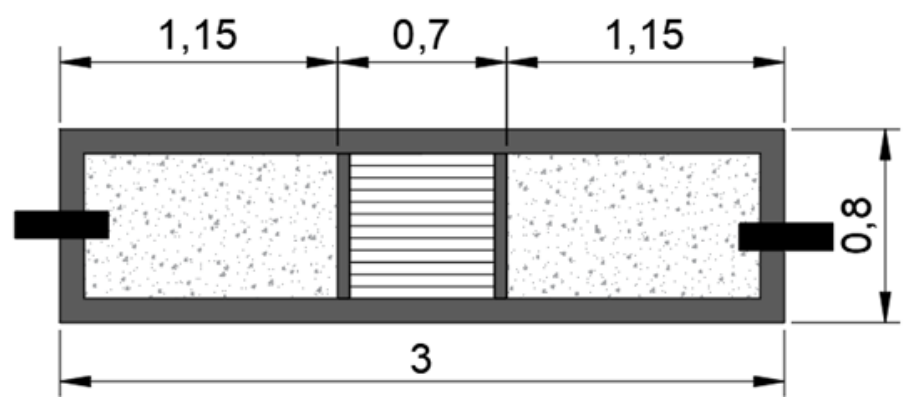

Figure 3. Technical Design of the Aerator Chamber

\subsection{Grid}

A hydraulic design of a stepped drop was made for the aerator, which has a slope of $20 \%$, with a ground slope of $38 \%$ and a total length of $1.00 \mathrm{~m}$. Figure 4 shows the hydraulic design of the aerator, where the dimensions of the system are detailed.

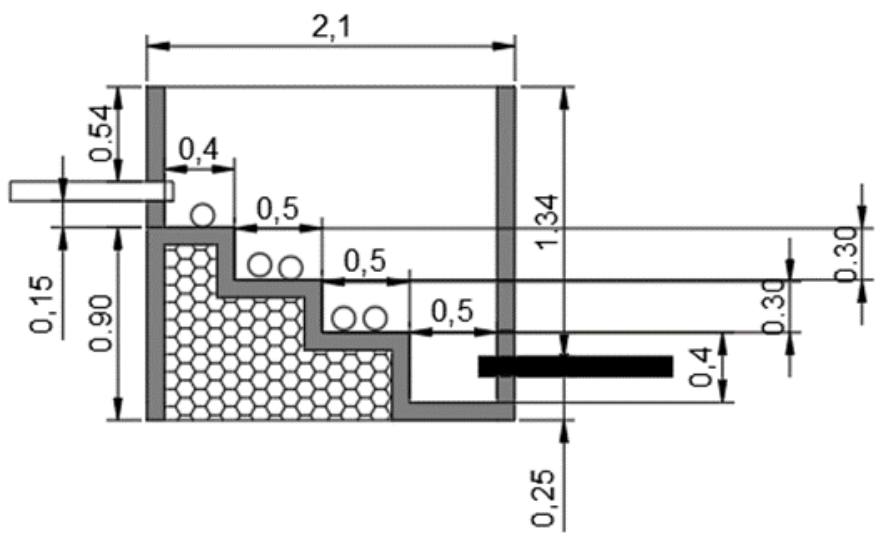

Figure 4. Hydraulic design of the aerator with a stepped drop 
3.8 Conventional settler

The conventional settler has been designed with a rectangular section and horizontal flow, based on the design flow $\mathrm{Q}=43.20 \mathrm{~m}^{\wedge} 3 / 24$, which will reach the system for its respective treatment. For the design, equation 2 Quiroz-Fernández et al., (2016) was used to determine the area and, in turn, the dimensions of the settler.

$$
A=\frac{Q}{v}=1,35 m^{2}
$$

From the calculated area, the conventional settler is dimensioned. In Figure 5 the dimensions of said settler are shown. For the drainage of the sludge, as detailed in the exposed graph, a corrugated PVC pipe of double wall of $300 \mathrm{~mm}$ of external diameter and $280 \mathrm{~mm}$ of internal diameter was chosen.

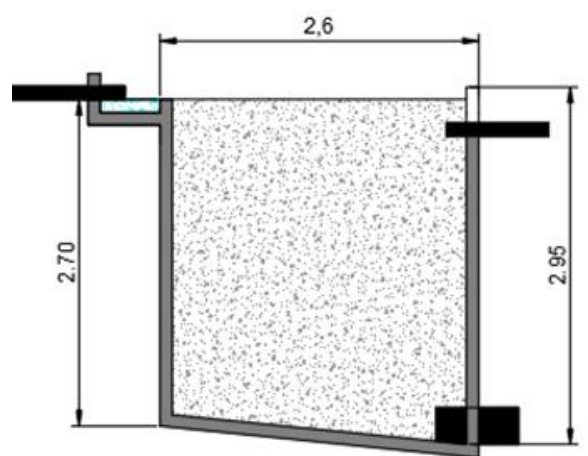

Figure 5. Dimensions of the conventional sedimentation system

\subsection{Zeolite filter}

A tubular system Loor \& Murillo (2017) was built for filtering and inside it four layers of zeolite with differentiated granulometry, that is four different sizes of the grains, was conditioned, in order to promote an adequate level of filtering and a fast retention time in the filtering system.

The zeolite of the clinoptilolite type was commercially acquired in the company zeonatec, located in the canton Isidro Ayora of the province of Guayas and grains were acquired with the following gravimetry: $1.70 \mathrm{~mm} ; 2 \mathrm{~mm} ; 2.63 \mathrm{~mm}$ and; $4.75 \mathrm{~mm} \mathrm{~A} 6$ "(inch) tube was used for the filtering device. Figure 6 shows a technical diagram with the gravimetric structure used for the construction of the filtering system (Loor \& Murillo, 2017).

Pinoargote, J. A. P., Alcivar, J. T. R., \& Viteri, C. G. V. (2018). Analysis and design of wastewater treatment. International Journal of Life Sciences, 2(3), 121-135. https://doi.org/10.29332/ijls.v2n3.221 


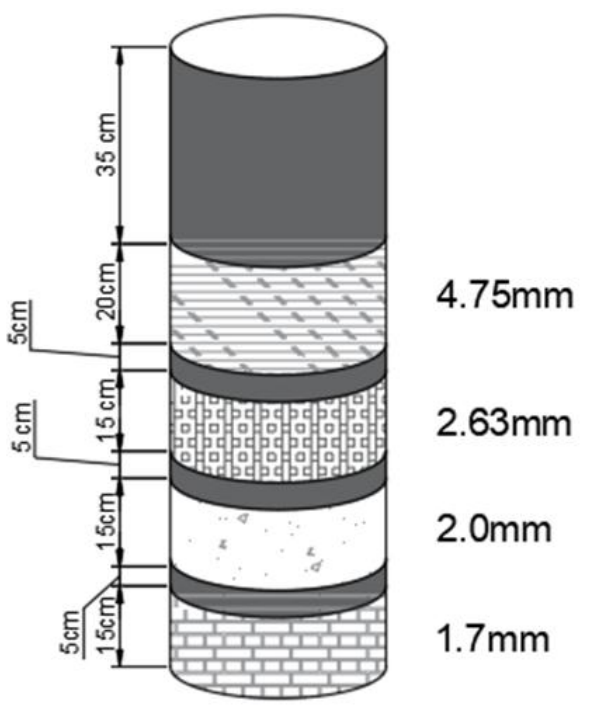

Figure 6. Structure of the zeolite filter

\subsection{Disinfection tank}

The function of the disinfection tank is to remove the remaining bacteria and viruses to meet the required water quality.

The design obeys to a volume capacity of $6.64 \llbracket \mathrm{m} \rrbracket^{\wedge} 3$, which has been calculated based on equation 3 that is expressed below. With a capacity of Chloriners of $86.4 \mathrm{Kg}$. Chlor. Day.

$\mathrm{V}=\mathrm{Q} * \mathrm{t} * 60 \mathrm{~min}$

Based on this calculated volume the tank is dimensioned which is detailed in figure 7.

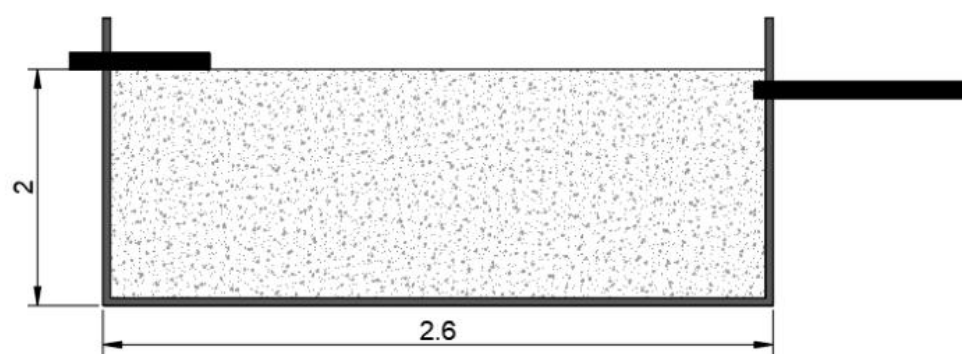

Figure 7. Detail of the dimensions of the disinfection tank

\subsection{Total performance of the wastewater treatment system}

For the purification performance of the treatment device, parameters that are outside the limit of environmental regulations must be taken into account with greater importance, in this case, they are: fecal coliforms, BOD, conductivity, dissolved total solids, and settleable solids.

The screening process theoretically removes around $3 \%$ to $5 \%$ of suspended solids, for the other parameters the removal is depreciable (Fair et al., 1973). Table 2 shows the data relating to the performance of wastewater pretreatment. 
Table 2

Wastewater pretreatment performance

\begin{tabular}{lllll}
\hline Parameters & $\begin{array}{l}\text { Effluent } \\
\text { concentration }\end{array}$ & $\begin{array}{l}\text { Assumed } \\
\text { theoretical }\end{array}$ & $\begin{array}{l}\text { removal Efficiency of } \\
\text { the removal }\end{array}$ & $\begin{array}{l}\text { Concentration that } \\
\text { passes to the next stage }\end{array}$ \\
\hline $\begin{array}{l}\text { Sedimentable solids } \\
\text { Suspended solids }\end{array}$ & $\begin{array}{l}7.33 \mathrm{~mL} / \mathrm{L} \\
233 \mathrm{mg} / \mathrm{L}\end{array}$ & $31 \%$ & $31 \%$ & $7.33 \mathrm{~mL} / \mathrm{L}$ \\
BOD5 & $526 \mathrm{mg} / \mathrm{L}$ & & & $233 \mathrm{mg} / \mathrm{L}$ \\
COD & $998 \mathrm{mg} / \mathrm{L}$ & & & $526 \mathrm{mg} / \mathrm{L}$ \\
\hline
\end{tabular}

On the other hand, the primary treatment removes around $30 \%$ to $40 \%$ of BOD, $30 \%$ to $40 \%$ of COD, $50 \%$ to $65 \%$ of suspended solids and settleable solids (Fair et al., 1973). Table 3 shows the data relating to the performance of the primary wastewater treatment.

Table 3

Performance of primary treatment of wastewater

\begin{tabular}{lllll}
\hline Parameters & $\begin{array}{l}\text { Effluent } \\
\text { concentration }\end{array}$ & $\begin{array}{l}\text { Assumed } \\
\text { theoretical }\end{array}$ & $\begin{array}{l}\text { Removal Efficiency } \\
\text { of the removal }\end{array}$ & $\begin{array}{l}\text { Concentration that } \\
\text { passes to the next stage }\end{array}$ \\
\hline Sedimentable solids & $7.33 \mathrm{~mL} / \mathrm{L}$ & $60 \%$ & $0 \%$ & $2.93 \mathrm{~mL} / \mathrm{L}$ \\
Suspended solids & $233 \mathrm{mg} / \mathrm{L}$ & $60 \%$ & $5 \%$ & $90.40 \mathrm{mg} / \mathrm{L}$ \\
BOD5 & $526 \mathrm{mg} / \mathrm{L}$ & $35 \%$ & $44 \%$ & $341.90 \mathrm{mg} / \mathrm{L}$ \\
COD & $998 \mathrm{mg} / \mathrm{L}$ & $35 \%$ & $63 \%$ & $648.70 \mathrm{mg} / \mathrm{L}$ \\
\hline
\end{tabular}

The secondary treatment removes about $65 \% 80 \%$ BOD, $65 \%$ to $80 \%$ COD, $60 \%$ to $70 \%$ suspended solids and settleable solids, for pathogenic microorganisms the removal is depreciable (Fair et al., 1973). Table 4 shows the data relating to the performance of secondary wastewater treatment.

Table 4

Secondary wastewater treatment performance

\begin{tabular}{lllll}
\hline Parameters & $\begin{array}{l}\text { Effluent } \\
\text { concentration }\end{array}$ & $\begin{array}{l}\text { Theoretical } \\
\text { removal } \\
\text { assumed }\end{array}$ & $\begin{array}{l}\text { Efficiency of the } \\
\text { removal }\end{array}$ & $\begin{array}{l}\text { Concentration that passes to } \\
\text { the next stage }\end{array}$ \\
\hline Sedimentable solids & $2,93 \mathrm{~mL} / \mathrm{L}$ & $70 \%$ & $0 \%$ & $0,88 \mathrm{~mL} / \mathrm{L}$ \\
Suspended solids & $90,40 \mathrm{mg} / \mathrm{L}$ & $70 \%$ & $0 \%$ & $27 \mathrm{mg} / \mathrm{L}$ \\
DBO5 & $342 \mathrm{mg} / \mathrm{L}$ & $75 \%$ & $4 \%$ & $85 \mathrm{mg} / \mathrm{L}$ \\
DQO & $649 \mathrm{mg} / \mathrm{L}$ & $75 \%$ & $19 \%$ & $162 \mathrm{mg} / \mathrm{L}$ \\
\hline
\end{tabular}

Then, a table of values is presented where the removal efficiency of the limits established by the standard is indicated. Table 5 shows the data relative to the total efficiency of the wastewater treatment system.

Table 5

Total efficiency of the wastewater treatment system

\begin{tabular}{llll}
\hline Parameters & $\begin{array}{l}\text { Effluent concentration } \\
\text { Initial }\end{array}$ & $\begin{array}{l}\text { Concentration of the } \\
\text { final effluent }\end{array}$ & $\begin{array}{l}\text { Total efficiency of the } \\
\text { treatment system }\end{array}$ \\
\hline Sedimentable solids & $7,33 \mathrm{~mL} / \mathrm{L}$ & $0,88 \mathrm{~mL} / \mathrm{L}$ & $88,00 \%$ \\
Suspended solids & $233 \mathrm{mg} / \mathrm{L}$ & $27,12 \mathrm{mg} / \mathrm{L}$ & $88,36 \%$ \\
DBO5 & $526 \mathrm{mg} / \mathrm{L}$ & $85,48 \mathrm{mg} / \mathrm{L}$ & $83,75 \%$ \\
DQO & $998 \mathrm{mg} / \mathrm{L}$ & $162,18 \mathrm{mg} / \mathrm{L}$ & $83,75 \%$ \\
\hline
\end{tabular}

Pinoargote, J. A. P., Alcivar, J. T. R., \& Viteri, C. G. V. (2018). Analysis and design of wastewater treatment. International Journal of Life Sciences, 2(3), 121-135. https://doi.org/10.29332/ijls.v2n3.221 


\subsection{Review of compliance with environmental regulations}

Table 6 shows the values of the comparison related to the initial concentration obtained through the laboratory analyzes performed in the WWTP and the final concentration calculated with the proposed treatment system, according to the terms indicated in the Unified Text of Legislation. Environmental Secondary (TULAS), Book VI-Annex 1 (Presidency, 1992), and the verification of compliance with said norm:

Table 6

Review of compliance with environmental regulations

\begin{tabular}{lllll}
\hline Parameter & $\begin{array}{l}\text { Parameter } \\
\text { Concentration of } \\
\text { the initial tributary }\end{array}$ & $\begin{array}{l}\text { Parameter } \\
\text { Concentration of the } \\
\text { initial tributary }\end{array}$ & $\begin{array}{l}\text { Permissible } \\
\text { limit }\end{array}$ & Fulfillment \\
\hline Sedimentable solids & $7,33 \mathrm{~mL} / \mathrm{L}$ & $0,88 \mathrm{~mL} / \mathrm{L}$ & $1,00 \mathrm{~mL} / \mathrm{L}$ & CUMPLE \\
Suspended solids & $233 \mathrm{mg} / \mathrm{L}$ & $27,12 \mathrm{mg} / \mathrm{L}$ & $220,00 \mathrm{mg} / \mathrm{L}$ & CUMPLE \\
DBO5 & $526 \mathrm{mg} / \mathrm{L}$ & $85,48 \mathrm{mg} / \mathrm{L}$ & $100,00 \mathrm{mg} / \mathrm{L}$ & CUMPLE \\
DQO & $998 \mathrm{mg} / \mathrm{L}$ & $162,18 \mathrm{mg} / \mathrm{L}$ & $250,00 \mathrm{mg} / \mathrm{L}$ & CUMPLE \\
\hline
\end{tabular}

\subsection{Análisis económico}

This wastewater treatment system with a zeolite filter is undoubtedly an economic proposal since this filter has a cost of \$1793.69 in reference to its size. Since the zeolite is an economic mineral that is extracted and marketed from the province of Guayas and that after its application does not generate other costs associated with the environmental pollution component since its use is practically harmless. $75 \%$ of the price is deducted for the civil works in the construction of the filter and $25 \%$ of the cost for the purchase of the zeolite and its application (Metacalf \& Hedí, 1995). The method of purification of wastewater by using zeolite is environmentally friendly and reduces the economic impact of environmental damage related to water pollution (Metacalf \& Hedí, 1995). For this wastewater treatment system, a detailed budget was made, which is shown in the following table 7; deducting a total cost for the system equivalent to \$ 8,013.37.

Table 7

Budget of the wastewater treatment system

\begin{tabular}{llllll}
\hline Items & Description of the subject & Unity & Quantity & $\mathrm{P} / \mathrm{u}$ & Total \\
\hline 1 & Preliminaries & & & & \\
1.1 & Replanting and layout & $\mathrm{M}^{2}$ & 83,00 & 1,00 & 83,00 \\
1.2 & Excavation & $\mathrm{M}^{3}$ & 42,00 & 4,00 & 168,00 \\
1.3 & Ball stone filling & $\mathrm{M}^{3}$ & 8,00 & 20,00 & 160,00 \\
1.4 & Filling improvement material & $\mathrm{M}^{3}$ & 20,00 & 16,00 & 320,00 \\
2 & Concrete structure & & & & \\
2.1 & Single concrete $180 \mathrm{~kg} / \mathrm{cm} 2$ for replantillo & $\mathrm{M}^{3}$ & 7,05 & 190,00 & 1339,50 \\
2.2 & Simple concrete 210 kg / cm2 walls & $\mathrm{M}^{3}$ & 9,12 & 200,00 & 1824,00 \\
2.3 & Simple concrete 210 kg / cm2 slabs & $\mathrm{M}^{3}$ & 2,20 & 200,00 & 440,40 \\
2.4 & Simple concrete 210 kg / cm2 staged fall & $\mathrm{M}^{3}$ & 0,40 & 200,00 & 80,00 \\
2.5 & Simple concrete 210 kg / cm2 rough & $\mathrm{M}^{3}$ & 0,58 & 200,00 & 115,20 \\
2.6 & Reinforcing steel & $\mathrm{Kg}$ & 10,65 & 2,00 & 21,31 \\
3 & Pipeline & & & & \\
3.1 & 40x40 registration box with cover with & $\mathrm{U}$ & 6,00 & 120,00 & 720,00 \\
& metal frame & & & & \\
3.2 & Excavation & $\mathrm{M}$ & 27,00 & 4,00 & 108,00 \\
3.3 & Water pipe served installation and sand bed & $\mathrm{Ml}$ & 280,00 & 3,00 & 840,00 \\
4 & Zeolite filter & $\mathrm{U}$ & 1,00 & 1793,96 & 1793,96 \\
\hline
\end{tabular}




\section{Conclusion}

a) The research allowed the design of a wastewater treatment system, which allows the reuse of said waters in the Faculty of Agricultural Engineering of the Technical University of Manabí, with possibilities of being used in the agricultural irrigation of the areas destined to the teaching and research culture of institution.

b) With the inclusion of a zeolite filter in the treatment system for wastewater, the water quality will be improved, since it lowers the polluting levels of the same, besides that said filter is $100 \%$ bioavailable, ecological and natural

c) When evaluating the estimation of the results obtained, it was demonstrated that as the water circulates through the designed treatment system, the levels of contamination are reduced until reaching the quality required in the standard for irrigation water

\section{Acknowledgments}

The authors would like to thank the reviewer for their consideration to review this article. Thank the editor of the journal for their valuable time, support and advice.

Pinoargote, J. A. P., Alcivar, J. T. R., \& Viteri, C. G. V. (2018). Analysis and design of wastewater treatment. International Journal of Life Sciences, 2(3), 121-135. https://doi.org/10.29332/ijls.v2n3.221 


\section{References}

Alcivar, M. S. G., Muñoz, S. R., Murillo, M. O., \& Gámez, M. R. Zeolite and the Removal of Ammonium in Sewage.

Castellón Gómez, J. J., Bernal Muñoz, R., \& Hernández Rodríguez, M. D. L. (2015). Calidad del agua para riego en la agricultura protegida en Tlaxcala. Ingeniería, 19(1).

Condorchem. (2010). Historia del tratamiento de agua potable. Rotterdamseweg, . Lenntech, Consultado el 29 de agosto 2018.

Fair, GM, Geyes, JC, \& Okum, DA (1973). Purificación de aguas y tratamientos y remoción de aguas residuales. Editorial limusa, primera edición, 1973.

Fernández, L. S. Q., Kulich, E. I., \& Gutiérrez, C. M. (2016). Modelación matemática de la capacidad de autodepuración de corrientes superficiales. Caso de estudio: Río Portoviejo, Ecuador. Revista Cubana de Ingeniería, 7(2), 64-70.

Hidalgo, Y. G. (2015). Calidad del agua con fines de riego. Ojeando la Agenda, (35), 1.

iagua. (2015). Publicada la nueva norma ISO 16075 para el uso agrícola de agua residual depurada. Consultado el 2 de noviembre de 2018.

INEN. (2017). Código Ecuatoriano de la construcción. (CEC) diseño de instalaciones sanitarias. CPE INEN 0059-2: Código de práctica para el diseño de sistemas de abastecimiento de agua potable, disposición de excretas y residuos líquidos en el área rural.

Lenntech. (2018). Calidad del agua para irrigación. Consultado el 10 de octubre de 2018.

Linzan, Á. R. A., Sauvanell, Á. L. B., \& Parra, M. I. F. (2018). Exergoeconomic and ecological efficiency analysis of steam generation system in ecuadorian tuna industry. International Research Journal of Engineering, IT and Scientific Research (IRJEIS), 4(2), 52-62.

Loor Bravo, H. A., \& Meza Vélez, G. W. (2017). Estudio para la implementación de un molino analítico para el uso del laboratorio de bromatología para la facultad de ciencias veterinarias de la universidad técnica de manabí. Extensión lodana (Bachelor's thesis).

Loor, AMV, \& Murillo, JMO (2017). Evaluación de la remoción de amonio en aguas residuales, empleando zeolita particulada de diferentes diámetros. Trabajo de titulación previo a la obtención del título de Ingeniero, Facultad de Ciencias Matemática, Física y Química de la Universidad Técnica de Manabí.

Metacalf;, \& Hedí. (1995). INC, Ingeniería de aguas residuales. Volúmenes 1 y 2, Ed. McGraw-Hill. Tercera edición.

Morales, SE. (2017). Norma de diseño para sistemas de abastecimiento de agua potable, disposición de excretas y residuos líquidos en el área rural. Universidad Central del Ecuador (UCE), Norma CO 10.7 - 602 Revisión.

Morillo, Á. (2017). Aguas negras el rastro de nuestra historia. wearewater Foundation, Consultado el 30 de agosto 2018.

Presidencia. (1992). Norma de calidad ambiental de descargas de efluentes: recurso agua. Presidencia de la República.

Presidencia. (2010). Norma de calidad y descarga de efluentes: Recurso agua. Quito, Ecuador: Presidencia de la República. Libro IV. Libro 1.

Ramalho, R. S. (1996). Tratamiento de Aguas Residuales Editorial Reverté. SA, España.

UN (2002). Declaración de Johannesburgo sobre el Desarrollo Sostenible. Tercera Cumbre Mundial de las Naciones Unidas sobre Ambiente y Desarrollo - 2002, Consultado el 2 de noviembre de 2018.

Vázquez, C. M. L., Méndez, G. B., García, H. A., \& Carrillo, F. J. C. Tratamiento biológico de aguas residuales. 


\section{Biography of Authors}

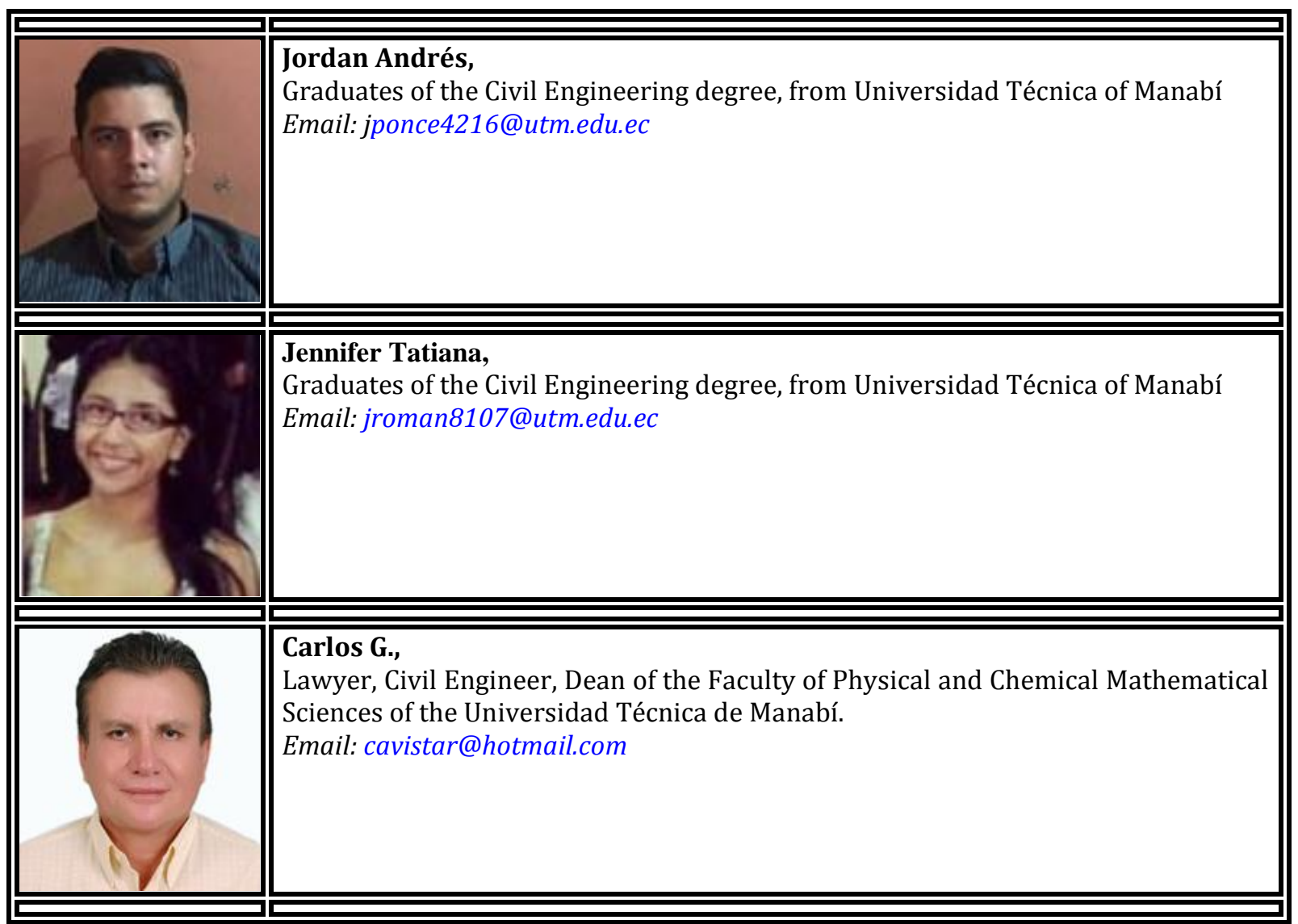

Pinoargote, J. A. P., Alcivar, J. T. R., \& Viteri, C. G. V. (2018). Analysis and design of wastewater treatment. International Journal of Life Sciences, 2(3), 121-135. https://doi.org/10.29332/ijls.v2n3.221 